\title{
Assessing Banking Profit Efficiency Using Stochastic Frontier Analysis
}

\author{
Riko Hendrawan, Azhar A. Nasution
}

Telkom University, Indonesia

\begin{abstract}
Objective - The banking sector plays an important role in the Indonesian economy. The sustainability of the Indonesian banking sector will depend on the ability of every banking institution to maintain their competitiveness. Banking competitiveness is reflected in the level of efficiency of the banking system itself.

Methodology/Technique - The purpose of this research is to assess the efficiency of 21 banks on the IDX between 2008-2017 using Stochastic Frontier Analysis.

Findings - The findings of this research show a maximum efficiency score of 0.69 and the bank's average score among the research sample with the input and output allocation which can generate profits is $0.69-0.43=0.26$. Overall, the banking sector in the Indonesian capital market between 2008 - 2017 recorded an efficiency score of 0.43 . With this score, the banking system in the Indonesian capital market is still considered to be inefficient $(0.43<0.5)$. The results also demonstrate that the distribution of efficiency scores polarized in two poles. In the first pole, there were 11 banks that had a relatively good efficiency score $(>=0,5)$ and in the second pole, there were 10 banks with low efficiency scores (less than 0.5).

Novelty - From the results, it can be concluded that several output variables, such as total loans (Y1) and securities (Y3), and input variables such as prices of labor (W2) and inflation (Z), have a significant effect on banking profits. Meanwhile, input variables such as the price of fund variables or the total funds (W1) and the price of physical capital were reflected in the depreciation of fixed assets (W3), and the output variables of income and interest (Y2) had an insignificant effect on bank profits.
\end{abstract}

Type of Paper: Empirical

Keywords: Bank Efficiency; IDX, Stochastic Frontier Analysis, Indonesia.

JEL Classification: G10, G14, G19.

\section{Introduction}

The banking sector plays an important role in the Indonesian economy. Referring to the data of 10 companies with the highest market capitalization in December 2017, four banking stocks were included on the list.

\footnotetext{
${ }^{*}$ Paper Info: Received: September 5, 2018

Accepted: December 10, 2018

* Corresponding author: Riko Hendrawan

E-mail: riko_hendrawan@yahoo.com

Affiliation: Telkom University, Indonesia
} 
These were: PT Bank Central Asia Tbk (BCA) with a market capitalization of up to IDR 530.1 trillion (7.59\%), PT Bank Rakyat Indonesia Tbk (BRI) with a market capitalization of up to IDR 426.8 trillion (6.29\%), PT Bank Mandiri (Persero) Tbk with a market capitalization of up to IDR 358.2 trillion (5.21\%) and PT Bank Negara Indonesia Tbk (BNI) with a market capitalization of up to IDR 183.7 trillion (2.6\%). Thus, in total, the four largest banks in Indonesia control $21.68 \%$ of the market capitalization.

The sustainability of the Indonesian banking sector depends on the ability of every banking institution to maintain their competitiveness. Banking competitiveness is reflected in the level of efficiency of the banking system itself. Based on the data obtained between 2013-2017 represented in Graph 1 below, the net income growth in 2014 recorded a negative performance at $-4 \%$ compared to 2013. In 2015, the net income repeatedly experienced a negative growth of $-4 \%$. In 2016, the banks in the new capital market began to gain a minimal positive growth at $1 \%$. In the following year, the net income growth reached $23 \%$. Generally, from 2013 to 2017, the average bank efficiency level has reached 4\% annually and has experienced double negative growth.

However, if it is examined using earnings per share (EPS), earnings growth per share in 2014 decreased to $-11 \%$ in comparison to 2013. This number declined further in 2015 (-4\% growth). In 2016, the decline of earnings per share reached $-12 \%$ compared to the previous year. However, the earnings per share improved in 2017 by 3\%, however no significant increase has occurred in the last 5 years. The average recorded earnings per share was $-6 \%$, decreasing to $23 \%$ in 2017 compared to the results obtained in 2013.

Graph 1. Comparison between Average Revenue, EBT, and EPS of Banking Sector in IDX (2013-2017)

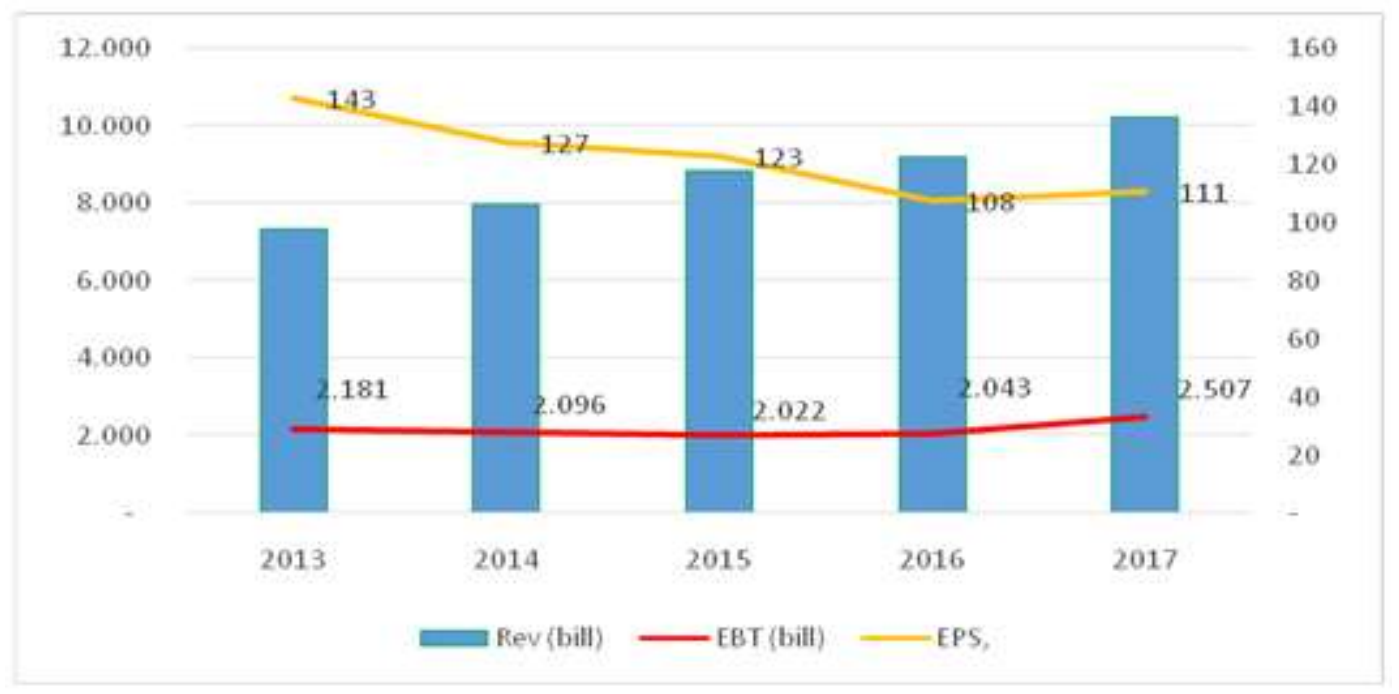

Given the important role of the banking sector in maintaining and improving company performance for the Indonesian economy, it is necessary to understand the efficiency of banks in generating profit. There are three banking efficiency measurement approaches that have been applied in previous studies: Distribution Free Approach (DFA), Stochastic Frontier Analysis, and Data Envelopment Analysis (DEA). The Distribution Free Approach (DFA) was applied by Maudos and Pastor (1999) in Europe, Kamberoglou (2004) in Greece, Al-Farisi and Hendrawan (2010) in Indonesia, and Delis, Filippaki, Staikouras and Gerogiannak (2012) in Greece. The Stochastic Frontier Analysis method has been applied by researchers such as Tahir, Bakar and Haron (2010) in Malaysia, Ngan (2014) in Vietnam, Al-hassan (2014) in Ghana and Stanek (2015) in Czech. Other studies have applied the Data Envelopment Analysis (DEA), such as Sufian (2007) in Singapore.

Based on the explanation above, it is crucial to investigate the condition of banking profitability in Indonesia's capital market. This research will analyze the efficiency of the banking sector using the input- 
output approach proposed by Farrel's efficiency theory (1957) which focuses on how the use of input is maximized to output, such as technical efficiency, and how the input is proportionally allocated to achieve allocative efficiency. The parametric method of Stochastic Frontier Analysis is used in this study. SFA is used to estimate the frontier limit and to measure the technical efficiency of a production.

\section{Literature Reviews}

\subsection{Efficiency Theory}

Farrel (1957) divides efficiency into technical efficiency and allocative efficiency. Technical efficiency reflects a company's ability to generate output with a number of available inputs, while allocative efficiency reflects the ability of firms to optimize their use of input with cost and technology structures. Frisch (1965) states that production is a process of transformation regulated by individuals, as desired by some parties. Transformation can be understood as the changing process of some goods and services in which they "lose their identity" and produce new goods and services.

De Young (1997) argues that comparing cost ratios between two banks is not appropriate because of the differences in product mix, product size, market conditions, and other characteristics that may affect the costs each bank incurs. Further, the accounting-based ratios are easy to establish and difficult to interpret. Damodaran (2002) states that measuring the value of a company is generally achieved by assessing the value of assets owned by the company rather than assessing its equity value. However, in the case of financial services companies, debt has different connotations. Most financial companies view debt as a raw material rather than as a source of capital.

The calculation of efficiency can be achieved by using the cost efficiency approach or profit efficiency approach. Fuentes and Vergara (2003) indicate that cost efficiency emphasizes the minimum cost required to produce output without error in determining the output mix based on the product's market price. Meanwhile, profit-efficiency considers the product mix as a decision variable. Berger and Di Patti (2003) further state that profit-efficiency is superior in describing the intermediary function than cost efficiency. This opinion is supported by Drake and Simper (2005).

\subsection{Previous Research}

Maudos and Pastor (1999) conducted a study on cost and profit-efficiency in the banking industry in 11 countries in the European Union. This research uses a Distribution Free Approach method. Three input variables and three output variables were used. The first input variable was the cost of loanable funds obtained by dividing the financial cost of corresponding liabilities. The second input variable was the cost of labor. This variable was obtained by dividing the personal expense by the number of employees. The third input variable was the cost of physical capital defined as the ratio between the expenditure on plant and equipment and the book value of physical capital. Loans, other assets, and loanable funds were used as the output variables in this study. The study concludes that high levels of inefficiency in costs and lower levels in profits will verify the significance of inefficiencies in the income of banking activity.

Kamberoglou (2004) conducted a study to determine the cost-efficiency of 18 banks in Greece between 1993 - 1999. The parametric method used was the Distribution Free Approach (DFA). The results show that bank characteristics such as bank size, type of ownership, and risk behavior can be used to explain differences in measured inefficiencies. The scale economies were also examined. The findings indicate that the Greek banking industry experiences economies of scale, however, they declined throughout the observed period. That study suggests that competitive viability may be an important factor for further consolidation in the Greek banking industry. 
Sufian (2007) conducted a study on the profitability of commercial banks in Singapore using the nonparametric method of Data Envelopment Analysis. This research applied two input variables: price of labor and capital which is the division of personal expense with total assets and price of deposit which is the income paid to depositors divided by total deposits. The output parameters used were the total earning assets, which is the sum of all loans, investments, and other productive assets. The results indicate that Singapore banking groups exhibited a total average or technical efficiency of $88.4 \%$. It can be noted that the overall efficiency of Singapore banking groups experienced a decline during the beginning period of the study, before increasing dramatically during the end of the study.

Delis, Filippaki, Staikouras and Gerogiannak (2008) conduct a comparison of parametric and nonparametric profit-value calculations in commercial banks in Greece between 1993-2005. The method of calculating the parameters with Stochastic Frontier Analysis (SFA) was compared with the non-parametric calculation method of Data Envelopment Analysis (DEA). The results demonstrate that the cost efficiency of the banks examined in the study was lower than the profit efficiency; this result meets the study expectations. However, the difference between the cost efficiency and profit efficiency was quite significant.

Tahir, Bakar and Haron (2010) conducted a study to compare the profitability of foreign banks in Malaysia with Malaysian local banks. This research uses a cost-profit calculation method with a parametric approach. This research employed two input variables: input price of labor and capital variable, and input price of deposit variable. For the output variable, total earnings and total assets were used. The study concludes that the average bank deviations were substantially derived from the best-practice frontier. The managerial inefficiencies of Malaysian commercial banks were found to be significant, with the average cost of efficiency for 22 banks at $80.6 \%$. This study further concludes that an average bank will incur $19.4 \%$ less actual costs when its performance is matched to the best performing bank. According to that study, domestic banks are more cost efficient than their foreign counterparts (80.6\% compared to $75.5 \%$ )

Al-Farisi and Hendrawan (2010) conducted a study to compare the profit efficiency between Indonesian conventional banks and Islamic banks between 2002-2008 with a parametric method which was the Distribution Free Approach. They conclude that 3 Islamic banks were among the $20 \%$ most efficient banks in Indonesia in terms of their intermediation function.

Mamatzakis, Filippaki and Pasiouras (2012) conducted a study to determine the efficiency of banks in Greece between 2000-2006. Their study uses three input variables and three output variables. The three input variables were cost of loaned funds, cost of labor, and cost of physical capital. The output variables were loans, other assets, and total deposits. The results show that there is a remarkable variation of efficiency across quantities and the estimations of the second stage regressions, illustrating the impact of various variables on cost efficiency.

Ngan (2014) performed a study examining the cost and profit-efficiency of banks in Vietnam. This research applies a Stochastic Frontier Analysis method. Three input variables and two output variables were used. The input variables used were price of physical capital, price of labor, and price of loanable funds. The output variables were total loans and total securities. The results show that the profit efficiency of Vietnamese commercial banks is around $61 \%-68 \%$ and their cost efficiency rose from about $8 \%$ to nearly $20 \%$ over the research period.

A study conducted by Al-Hassan (2015) identified the non-linear relationship between income diversification and cost-profit of 23 Banks in Ghana between 2003 and 2011. The cost-profit efficiency was calculated using the Stochastic Frontier Analysis method. This research shows that the SFA revealed high levels of efficiency in cost compared to the profit efficiency, reflecting high inefficiencies in revenue. An analysis of the efficiency scores measured by two categories of bank size shows that the big banks have higher cost and profit efficiency in comparison to the small banks. A non-linear relationship was also identified between income diversification and efficiency. Size was also found to be important in enabling banks to achieve the potential benefits of income diversification. 


\section{Research Methods}

The method used to measure the efficiency of the capital market in the banking sector was the parametric approach of Stochastic Frontier Analysis. The analysis unit in this study was commercial banks in the Indonesian capital market between 2008 and 2017. In total, there were 21 open banks listed in that period. The input variables used in this research were price of funds, price of labor, and price of physical capital with the following explanation:

The input variables (y) include:

$\mathrm{w} 1=$ Price of Funds $=$ total interest expenses $/$ total funds

$\mathrm{w} 2=$ Price of Labor $=$ personal expense $/$ total assets

w3 = Price of Physical Capital $=$ depreciation $/$ fixed assets

Price of Funds is the division of total interest with total funds. This parameter explains the function of the bank as an intermediary. This parameter was used by Kamberoglou (2004) and Delis, Filippaki, Staikouras and Gerogiannak (2008).

Price of Labor refers to the costs incurred by the company for labor compared to the total assets owned by the company. This parameter describes the production function of labor. In a previous study, Alhassan (2015) uses the price of labor as an input variable.

Price of Physical Capital is the ratio of depreciation to fixed assets. This parameter addresses the production factor as the cost of capital. This parameter was adopted by Maudos and Pastor (1999).

The output variables represented the main source of income from the banking company. The output variables used were total loans, net non-interest income, and securities with the following details:

The output variables (y) include:

$\mathrm{y} 1=$ Total loans $=$ gross loans

y2 $=$ Net non-interest income $=$ Other Earning Assets

y3 $=$ Securities

Total loans is used to measure the output of a function-based bank as a fund intermediary. This variable has previously been adopted by Joaquín and Pastor (1999), Kamberoglou (2004), Sufian (2007), and Delis, Filippaki, Staikouras and Gerogiannak (2012).

Net non-interest income is used to measure the output of a fee-based bank. This has previously been used by Kamberoglou (2004) and Delis, Filippaki, Staikouras and Gerogiannak (2008).

Securities is used to measure the output of security-based banks. This has previously been used by AlFarisi and Hendrawan (2010), Delis, Filippaki, Staikouras and Gerogiannak (2012), Ngan (2014) and Staněk (2015).

While the environmental variable represents an uncontrolled variable that may affect the company's earnings. This research uses inflation as the environment variable.

The environment variables (y) includes:

$\mathrm{K}=$ Inflation between 2008 and 2017

Al-Farisi and Hendrawan (2012) have previously used an environmental variable in their research. 


\section{Analysis Method}

To obtain an efficient analysis using the Stochastic Frontier Analysis method, profit (P) was used as a dependent variable. The input variables, output variables, and environmental variables acted as independent variables.

$\mathrm{P}=f(\mathrm{Y}, \mathrm{W}, \mathrm{Z})+\dot{\varepsilon}$

with the errors formulated with

$\dot{\varepsilon}=V_{i t}+U_{i t}$

The above equation can be written in natural logarithm:

$\operatorname{Ln}\left(P_{i t}\right)=\ln P_{i t}\left(Y_{i t}, W_{i t}, Z\right)+\dot{\varepsilon}$

$\operatorname{Ln} P_{i t}=\beta_{0}+\beta_{1} \ln \left(Y 1_{i t}\right)+\beta_{2} \ln \left(Y 2_{i t}\right)+\beta_{3} \ln \left(Y 3_{i t}\right)+\beta_{4} \ln \left(W 1_{i t}\right)+\beta_{5} \ln \left(W 2_{i t}\right)+\beta_{6} \ln \left(W 3_{i t}\right)+\beta_{7} \ln \left(Z_{i t}\right)+$ $V_{i t}+U_{i t}$

Profit-efficiency is defined as the ratio of the bank's actual profit to the maximum profit that may be achieved by the bank with the highest score.

$P_{R O E F F}=\frac{P_{i}}{P_{\max }}=\frac{\exp [\mathrm{f}(\mathrm{y}, \mathrm{w}, \mathrm{z})] \times \exp \left(\ln v_{i t}\right)}{\exp [\mathrm{f}(\mathrm{y}, \mathrm{w}, \mathrm{z})] \times \exp \left(\ln v_{\max }\right)}$

The input and output variables from the previous stage were used to calculate the determinant factor and efficiency value of each banking company using the Stochastic Frontier Analysis (SFA) method.

\section{Research Results and Discussion}

The findings of this research are seen in Table 1 below. From the efficiency level score measurement (scale 0 - 1) of the banking industry in the Indonesian capital market within 10 years (2008 - 2017), this study found that Bank Rakyat Indonesia (Persero) Tbk was the most efficient bank with an efficiency score of 0.69, followed by Bank Central Asia Tbk and Bank Mandiri (Persero) Tbk. Both of those banks shared the same efficiency score of 0.67. Some inefficient banks in the Indonesian capital market include Bank Permata Tbk (0.07), Bank Maybank Indonesia Tbk (0.07), and Bank QNB Indonesia Tbk (0.005).

This parametric measurement employed the profit approach to maximize output. This means that the company that was able to generate the largest profit from available input was the most profit-efficient company. These banks include Bank Rakyat Indonesia (Persero) Tbk, Bank Central Asia Tbk, and Bank Mandiri (Persero) Tbk. The above three companies were able to generate greater profits than other banks in the capital market while effectively maintaining their input. Bank Rakyat Indonesia (Persero) Tbk was able to collect the average profit of Rp. 17 trillion. Bank Central Asia Tbk collected an average profit of Rp.12.9 trillion. Bank Mandiri (Persero) collected an average profit of Rp.12 trillion.

The fourth largest profit producer was Bank Negara Indonesia (Persero) Tbk, with an average profit of Rp.6.5 trillion. However, from the efficiency score, Bank Negara Indonesia (Persero) Tbk was in the eighth position with a score of 0.54 . This means that Bank Negara Indonesia (Persero) Tbk has not optimized its production factors to generate profit. The remaining banks did not have a lower efficiency score. These banks therefore must improve their ability to maximize profits from their existing resources and production factors. 
Table 1. Level of Banking Efficiency in the Indonesian Capital Market

\begin{tabular}{|c|c|c|}
\hline No & Bank & eff.-est. \\
\hline 1 & Bank Rakyat Indonesia (Persero) Tbk. & 0.69 \\
\hline 2 & Bank Central Asia Tbk. & 0.67 \\
\hline 3 & Bank Mandiri (Persero) Tbk. & 0.67 \\
\hline 4 & Bank Tabungan Pensiunan Nasional Tbk. & 0.64 \\
\hline 5 & Bank Mayapada Internasional Tbk. & 0.59 \\
\hline 6 & Bank Pan Indonesia Tbk. & 0.59 \\
\hline 7 & Bank Bumi Arta Tbk. & 0.56 \\
\hline 8 & Bank Negara Indonesia (Persero) Tbk. & 0.54 \\
\hline 9 & Bank Danamon Indonesia Tbk. & 0.54 \\
\hline 10 & Bank Bukopin Tbk. & 0.51 \\
\hline 11 & Bank Victoria International Tbk. & 0.50 \\
\hline 12 & Bank Capital Indonesia Tbk. & 0.49 \\
\hline 13 & Bank Mega Tbk. & 0.47 \\
\hline 14 & Bank OCBC NISP Tbk. & 0.45 \\
\hline 15 & Bank CIMB Niaga Tbk. & 0.45 \\
\hline 16 & Bank Artha Graha Internasional Tbk. & 0.27 \\
\hline 17 & Bank Rakyat Indonesia Agroniaga Tbk. & 0.16 \\
\hline 18 & Bank Nusantara Parahyangan Tbk. & 0.13 \\
\hline 19 & Bank Permata Tbk. & 0.07 \\
\hline 20 & Bank Maybank Indonesia Tbk. & 0.07 \\
\hline \multirow[t]{2}{*}{21} & Bank QNB Indonesia Tbk. & 0.005 \\
\hline & Average Efficiency Score & 0.43 \\
\hline
\end{tabular}

Furthermore, Figure 1 below shows the distribution of bank efficiency scores polarized in two poles. In the first pole, there were 11 banks that had a relatively good efficiency score (>=). These include Bank Rakyat Indonesia Tbk, Bank Central Asia Tbk, Bank Mandiri (Persero) Tbk, National Pension Savings Bank Tbk, Mayapada International Bank Tbk, Bank Pan Indonesia Tbk, Bank Bumi Arta Tbk, Bank Negara Indonesia (Persero) Tbk, Bank Danamon Indonesia Tbk, Bank Bukopin Tbk, and Bank Victoria International Tbk. In the second pole, there were 6 banks that had low efficiency score (less than 0.5). These include Bank Capital Indonesia Tbk, Bank Mega Tbk, Bank OCBC NISP Tbk and Bank CIMB Niaga Tbk. , Bank Artha Graha International Tbk, Bank Rakyat Indonesia Agroniaga Tbk, Bank Nusantara Parahyangan Tbk, Bank Permata Tbk, Bank Maybank Indonesia Tbk, and Bank QNB Indonesia Tbk. From the overall efficiency score calculation, these 10 banks were considered as the "load" of efficiency scores for the banking industry in the Indonesian capital market. The banking sector in the Indonesian capital market between 2008 and 2017 recorded an overall efficiency score of 0.43 . From these results, it can be concluded that, with a maximum efficiency score of 0.69 , the average score of banks in the research sample specified with certain input and output allocation can generate profits worth $0.69-0.43=0.26$. 
Figure 1. Efficiency Level Distribution

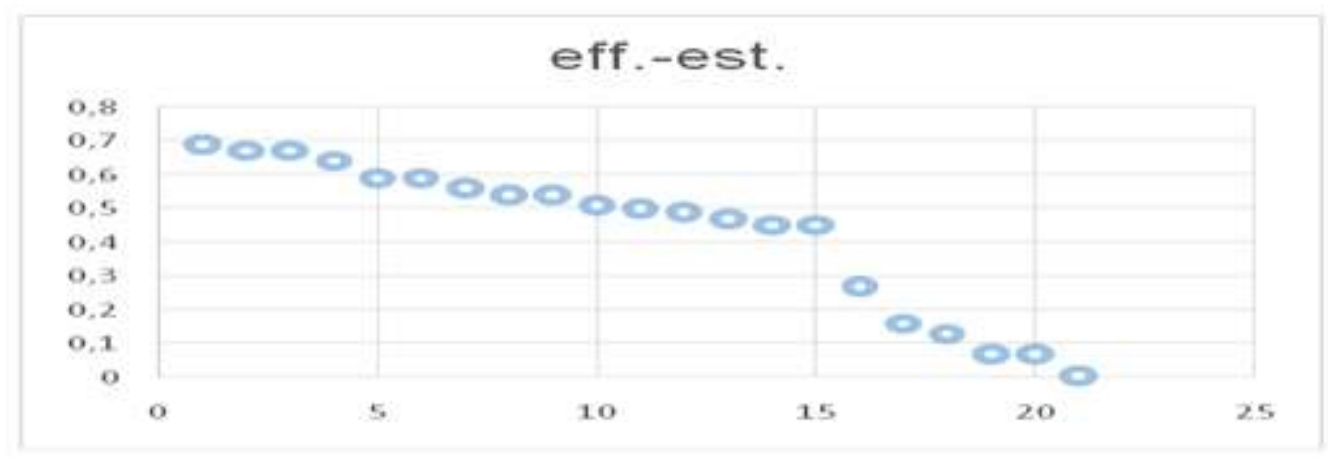

\section{Effect of Input, Output, and Environmental Variables on Banking Profit}

The Stochastic Frontier Analysis test results shown in Table 2 below show the estimation results of the factors that influence the profit variables. The results show that several output variables including total loans (Y1) and securities (Y3), and input variables including price of labor (W2) and inflation (Z), have a significant effect on banking profits. Meanwhile, input variable such as price of funds or total funds (W1) and the price of physical capital were reflected by the depreciation of fixed assets (W3), and the output variables such as income and interest (Y2) had an insignificant effect on banking profits.

The loan channeled (Y1) in this study had a significant and positive influence on the T-ratio at 3.6 (significant at $\alpha=10 \%$ ). The coefficient obtained was positive at 0.69 . This indicates that the credit relationship channeled with profit growth has a positive relationship. This means that if there is an increase in credit disbursed, the profit of the banking company will also increase. This is consistent with the findings of Al-Farisi and Hendrawan (2012). Further, the Y3 output variable have a significantly positive effect on the Tratio at 1.91 (significant at $\alpha=1 \%$ ). The coefficient obtained was positive at 0.1 . This means that there is a positive relationship between securities owned and profit growth. Thus, if there is an increase in securities owned, the profit of the banking company will also increase. This is consistent with the findings of Al-Farisi and Hendrawan (2012).

Price of labor (W2) was also shown to have a significant positive effect on the T-ratio at 1.82 (significant at $\alpha=1 \%$ ). The coefficient obtained was positive at 49.32. This means that labor costs are directly proportional to profit growth, while total assets are inversely proportional to banking profits. This is consistent with the findings of Al-Farisi and Hendrawan (2012).

The environment variable $\mathrm{Z}$, inflation, has a significantly positive effect on bank earnings with the T-ratio obtained at 2.92 (significant at $\alpha=10 \%$ ). The coefficient obtained was positive at 12.83 . This means that there is a positive relationship between inflation and profit growth. This means that if there is an increase in inflation, the profit of the banking company will also increase.

Table 2. Test Results in the Influence of Input, Output and Environment Variables on Profit

\begin{tabular}{|c|c|c|c|c|c|c|}
\hline & coeff & $\begin{array}{c}\text { Standard } \\
\text { Error }\end{array}$ & t-ratio & Var & Remark & Sig \\
\hline beta 0 & -2.67 & 2.25 & -1.19 & & & \\
\hline beta 1 & -6.99 & 7.29 & -0.96 & W1 & Price of funds & $*$ \\
\hline beta 2 & 49.32 & 27.07 & 1.82 & W2 & Price of Labor & $*$ \\
\hline beta 3 & -0.28 & 0.54 & -0.52 & W3 & Price of Physical capital & \\
\hline
\end{tabular}




\begin{tabular}{|c|c|c|c|c|c|c|}
\hline beta 4 & 0.69 & 0.19 & 3.60 & Y1 & Total loans & *** \\
\hline beta 5 & 0.18 & 0.15 & 1.21 & Y2 & Net non-interest income & \\
\hline beta 6 & 0.10 & 0.05 & 1.91 & $\mathrm{Y} 3$ & Securities & * \\
\hline beta 7 & 12.83 & 4.39 & 2.92 & $\mathrm{Z}$ & Inflation & *** \\
\hline sigma-squared & 7.41 & 1.26 & 5.88 & & & \\
\hline gamma & 0.42 & 0.10 & 4.28 & & & \\
\hline
\end{tabular}

\section{Conclusion}

Based on the results of this study, it can be concluded that the banking sector in the Indonesian capital market between 2008 and 2017 recorded an efficiency score of 0.43 . Therefore, the banking sector in Indonesia is still not efficient $(0.43<0.5)$. Bank Rakyat Indonesia (Persero) Tbk was the most efficient bank in Indonesia with an efficiency score of 0.69, followed by Bank Central Asia Tbk and Bank Mandiri (Persero) Tbk (third place) which shared the same score of 0.67.

The distribution of efficiency scores was polarized in two categories. In the first pole, there were 11 banks with a relatively good efficiency score $(>=0,5)$. In the second pole, there were 10 banks that had low efficiency score (less than 0.5). From the results, it can be concluded that several output variables, including total loans (Y1), securities (Y3), and certain input variables such as the price of labor (W2) and inflation (Z) have a significant effect on banking profits. Meanwhile, input variable such as price of funds or the total funds (W1) and the price of physical capital reflected by depreciation of fixed assets (W3), and output variables such as income and interest (Y2) have an insignificant effect on bank profits.

This research explains why Bank Rakyat Indonesia (Persero) Tbk is the most efficient bank in Indonesia. Bank Rakyat Indonesia (Persero) Tbk is able to optimize significant input-output variables to maximize their profit. This company is able to obtain benefits from managing their prices of labor (W2), total loans (Y1) and securities (Y3), to generate the highest profit among all Indonesian banks.

There are several possible opportunities for further research. This research may be continued to determine the effect of other significant variables on bank profits. The efficiency score may also be used as an independent variable to measure the effect of bank efficiency on bank performance.

\section{References}

Al-Farisi, A. S and Hendrawan, R. (2010). Measuring Efficiency as Intermediation Approach Between Conventional and Sharia Bank in Indonesia. Journal of Finance and Banking, 14 (3), 501-508.

Al-Farisi, A. S and Hendrawan, R. (2012). Effect of Capital Structure on Bank Performance: Profit Efficiency Approach Islamic and Conventional Banks Case in Indonesia. International Research Journal of Finance and Economics. ISSN 1450-2887 Issue 86.

Alhassan, Abdul Latif. (2015). Income Diversification and Bank Efficiency in an Emerging Market. Managerial Finance, 41(12), 1318-1335, https://doi.org/10.1108/MF-12-2014-0304. Retrieved from Emerald Insight.

Berger, Allen N. and Emilia Bonaccorsi di Patti (2003). Capital Structure and Firm Performance: A New Approach to Testing Agency Theory and an Application to The Banking Industry, Federal Reserve System Papers, USA.

Delis, Manthos D., Anastasia K-Filippaki, Christos Staikouras and Katerina Gerogiannak (2008). Evaluating Cost and Profit Efficiency: A Comparison of Parametric and Nonparametric Methodologies. Munich Personal RePEc Archive Paper No. 14039, posted 13 March 2009 06:16 UTC, http://mpra.ub.uni-muenchen.de/14039/.

De Young, Robert. (1997). Measuring Bank Cost Efficiency: Don't Count on Accounting Ratios. Financial Practice and Education, Washington, USA. 
Drake L and R Simper (2003). The Measurement of English and Welsh Police Force Efficiency: A Comparison of Distance Function Models. EJOR 147(1): 165-186.

Farrell M. J. (1957). The Measurement of Productive Efficiency. Published by: Wiley for the Royal Statistical Society Kamberoglou, CN. (2004) Cost Efficiency in Greek Banking. Bank of Greece Working Paper.

Mamatzakis, E. Anastasia, Koutsomanoli-Filippaki and Fotios Pasiouras (2012). A Quantile Regression Approach to Bank Efficiency Measurement. Munich Personal RePEc Archive MPRA Paper No. 51879. Online at http://mpra.ub.unimuenchen.de/51879/.

Maudos, Joaquín. and Pastor, José Manuel (1999). Cost and Profit Efficiency in European Banks. Instituto Valenciano de Investigaciones Económicas, S. A. First Edition September 1999.

Ngan, Le Thi Thanh (2014). Profit and Cost Efficiency Analysis in Banking Sector: A Case of Stochastic Frontier Approach for Vietnam. Scientific Papers (www.scientificpapers.org), Journal of Knowledge Management, Economics and Information Technology, 4(5).

Staněk, Rostislav. (2015). Determinants of Bank Efficiency: Evidence of Czech Banking Sector. Acta Universitatis Agriculturae Et Silviculturae Mendalianae Brunensis, 63(3). http://dx.doi.org/10.11118/actaun201563031005.

Sufian, F. (2007). Trends in the efficiency of Singapore's commercial banking groups: A non-stochastic frontier DEA window analysis approach. International Journal of Productivity and Performance Management, 56(2), 99-136.

Tahir, I. M., Bakar, N. M. A., \& Haron, S. (2010). Cost and profit efficiency of the Malaysian commercial banks: A comparison between domestic and foreign banks. International Journal of Economics and Finance, 2(1), 186. 